\title{
ANALISIS KEMAMPUAN PEMECAHAN MASALAH DITINJAU DARI MOTIVASI BELAJAR SISWA MTS
}

\author{
Feni Maisyaroh Agsya ${ }^{1}$, Maimunah $^{2}$, Yenita Roza ${ }^{3}$ \\ 1,2,3 Universitas Riau \\ ²maimunah@lecturer.unri.ac.id
}

\begin{abstract}
ABSTRAK
Kemampuan pemecahan masalah menjadi kemampuan paling mendasar di dalam matematika yang harus dilatihkan guru kepada siswa. Motivasi belajar yang berbeda diantara siswa dapat mempengaruhi kemampuan siswa dalam memecahkan masalah.Penelitian ini bertujuan untuk mendeskripsikan kemampuan pemecahan masalah siswa sesuai dengan tingkatan motivasi belajar (1) Tinggi, (2) Sedang (3) Rendah. Subjek dalam penelitian ini adalah 20 orang siswa kelas IX B MTs Thariqul Hidayah Danau Baru. Metode yang digunakan pada penelitian ini adalah deskripif kualitatif. Teknik pengumpulan data yang digunakan adalah teknik tes dan teknik non-tes, teknik tes menggunakan lembar tes kemampuan pemecahan masalah, teknik non-tes menggunakan angket motivasi belajar dan pedoman wawancara. Hasil penelitian menunjukkan bahwa siswa dengan motivasi belajar tinggi memiliki kemampuan pemecahan masalah yang cenderung baik, siswa mampu mememuhi empat indikator pemecahan masalah menurut Polya yaitu (1) memahami masalah, (2) membuat rencana, (3) melaksanakan rencana, (4) mengecek kembali. Siswa dengan motivasi belajar sedang memiliki kemampuan pemecahan masalah sedang, siswa mampu memenuhi indikator memahami masalah dan membuat rencana tetapi siswa bermasalah dalam melaksankan rencana penyelesaian.Siswa dengan kemampuan pemecahan masalah rendah memiliki kemampuan pemecahan masalah yang juga rendah, siswa mampu memahami masalah tetapi tidak mampu menentukan rencana penyelesaian yang akan dipilih.
\end{abstract}

Kata kunci : Kemampuan pemecahan masalah, Motivasi belajar, Teori polya

\begin{abstract}
ABSTRAK
Problem solving abilities becomes very basic abilities in math that should be trained by teacher to students. Having different motivation to study may affect students` problem solving abilities. This research aims to describe students` problem solving abilities in line with students motivation to study (1) High, (2) Medium (3) Low. The subject of this research was 20 students grade IX B of MTs Thariqul Hidayah Danau Baru. The method used was qualitative descriptive. The data were collected by using test and non-test technique; test technique used problem solving abilities test sheet and non-test technique uses questionnaire and interview. The result shows that students who have high motivation in studying have good problem solving abilities; students fulfill four indicators of problem solving of Polya; they are (1) understanding the problem, (2) planning, (3) carrying out the plan, (4) Rechecking. Students who have medium motivation in studying have average problem solving abilities; they reached understanding problem and planning indicator, however they found obstacle in carrying out the plan. Students who have low motivation in studying also have low problem solving abilities; they understood the problem, but they did not able to determine planning.
\end{abstract}

Keywords : Problem Solving abilities, Motivation study, Polya theory

\section{PENDAHULUAN}

Masalah matematika menurut Nisak (2017) adalah apabila pertanyaan atau soal yang diberikan memiliki suatu tantangan untuk diselesaikan, dan prosedur penyelesaiannya 
tidak dapat dilakukan dengan cara rutin. Kemampuan pemecahan masalah menurut Aisyah (2018) tidak hanya mengharuskan siswa untuk menyelesaikan suatu permasalahan dengan cara yang disampaikan guru, tetapi lebih kepada proses untuk mengelaborasikan kemampuannya, sehingga siswa dapat menemukan kombinasi-kombinasi aturan yang telah dipelajarinya terlebih dahulu dan menjadi suatu cara baru untuk dapat mempertimbangkan proses dalam memecahkan masalah matematika. Artinya, kemampuan pemecahan masalah merupakan suatu kemampuan berfikir tingkat tinggi yang mengharuskan siswa untuk mampu menggabungkan seluruh pengetahuan yang sudah didapatkan agar menjadi satu pengetahuan baru yang bisa di gunakan untuk menyelesaikan permasalahan.

Kemampuan pemecahan masalah menjadi kemampuan penting yang paling mendasar dalam matematika, karena kemampuan pemecahan masalah dapat membantu siswa dalam memecahkan persoalan baik di dalam pelajaran ataupun dalam kehidupan sehari-hari. Kegiatan pemecahan masalah menurut Yusri (2018) masih dianggap sebagai salah satu bahan yang sulit dalam matematika, walaupun kegiatan ini penting namun kenyataan di sekolah masih banyak siswa yang tidak mampu untuk menyelesaikan masalah. Menurut Ayu (2016). Siswa dikatakan mampu memecahkan masalah matematika jika mereka dapat memahami, memilih strategi yang tepat, kemudian menerapkannya dalam penyelesaian masalah. Kemampuan siswa memecahkan masalah dapat dilihat dari beberapa langkah. Polya dalam Vendiagrys dan Junaedi (2015) menyatakan bahwa langkah- langkah pemecahan masalah meliputi: (1) understanding the problem (memahami masalah), (2) devising a plan (membuat rencana), (3) carrying out the plan (melaksanakan rencana), (4) looking back (memeriksa kembali).

Kemampuan pemecahan masalah siswa pada kabupaten Indragiri Hulu masih tergolong rendah dibanding dengan kabupaten lainnya di provinsi Riau. Hal ini dapat dilihat dari tabel hasil ujian nasional matematika untuk SMP/MTS tahun 2017/2018 dan 2018/2019 pada Tabel 1.

Kabupaten Indragiri Hulu menjadi kabupaten dengan nilai matematika terendah ke dua di provinsi Riau untuk tingkat SMP/MTS selama dua tahun berturut-turut. Peningkatan yang terjadi hanya sebesar 4,5 poin saja dari tahun 2017/2018. Rendahnya kemampuan pemecahan masalah siswa ini tentu menjadi masalah serius dan harus segera diselesaikan oleh guru mata pelajaran agar kedepannya siswa Indragiri Hulu mampu bersaing dengan siswa kabupaten atau provinsi lain sehingga tercipta sumber daya manusia yang berkualitas sesuai dengan yang diharapkan oleh kurikulum. 
Tabel 1. Data Hasil Ujiam Nasional Matematika tingkat SMP/MTS Provinsi Riau

\begin{tabular}{ccc}
\hline Kabupaten/Kota & $\mathbf{2 0 1 7 / 2 0 1 8}$ & $\mathbf{2 0 1 8} / \mathbf{2 0 1 9}$ \\
\hline Pekanbaru & 44,70 & 50,40 \\
Indragiri Hilir & 59,55 & 50,13 \\
Bengkalis & 48,28 & 49,80 \\
Dumai & 42,11 & 44,13 \\
Kepulauan Meranti & 47,17 & 39,21 \\
Rokan Hilir & 47,24 & 44,48 \\
Rokan Hulu & 37,88 & 40,77 \\
Pelalawan & 41,52 & 50,81 \\
Kampar & 38,41 & 42,45 \\
Indragiri Hulu & 35,17 & 39,67 \\
Siak & 38,78 & 41,88 \\
Kuantan Singingi & 32,43 & 54,04 \\
\hline
\end{tabular}

Berdasarkan hasil wawancara dengan guru matematika di MTS Thariqul Hidayah Danau Baru diperoleh informasi bahwa setiap mendapat soal berbentuk masalah sebagian siswa masih kesulitan untuk mengubah infomasi yang diketahui ke dalam bahasa matematika, kesulitan untuk mengubah informasi ke dalam bahasa matematika akan berakibat pada kurangnya informasi yang diperoleh siswa untuk melanjutkan pekerjaanya. Siswa belum mampu menentukan rencana yang akan dilakukan untuk menyelsaikan masalah yang diberikan, hanya sebagian siswa yang mampu menentukan rencana dan melaksanakan rencanya penyelesaian. Siswa yang sudah mendapatkan hasil penyelesaian dari masalah yang diberikan jarang mengecek kembali jawaban mereka sehingga sering ditemui kesalahan-kesalahan dalam perhitungan yang menyebabkan jawaban mereka kurang tepat. Siswa yang tidak mampu menyelesaikan masalah sering terlihat tidak bersemangat dan hanya menunggu jawaban dari siswa lainnya. Alasan paling sering muncul ketika diberikan pertanyaan mengapa siswa tidak mampu menyelesaikan masalah adalah karena berbeda dengan contoh-contoh yang sudah diberikan oleh guru.

Rendahnya kemampuan pemecahan masalah siswa ini dapat disebabkan oleh beberapa faktor salah satunya dalah faktor motivasi. Motivasi belajar menurut Warti (2016) adalah kemauan, keinginan dan daya yang mendorong seseorang untuk melakukan suatu hal, motivasi belajar siswa sangat berpengaruh pada hasil belajar yang diperoleh. Sementara menurut Cleopatra (2015) motivasi merupakan seperangkat daya ataupun kekuatan dalam jiwa yang harus diterjemahkan oleh seseorang ke dalam bentuk perilaku yang sesuai dengan tuntutan yang timbul dari dalam (internal) dirinya maupun oleh dorongan dan lingkungannya (eksternal). Jadi, motivasi belajar adalah faktor yang menyebabkan munculnya keinginan dari dalam diri siswa untuk melakukan aktivitas belajar tanpa adanya paksaan untuk mendapatkan hasil belajar yang maksimal. 
Motivasi belajar dibagi menjadi dua yaitu motivasi ekstrinsik yang berasal dari luar diri siswa dan motivasi intrinsik yang berasal dari dalam diri siswa. Motivasi belajar dapat dilihat dari beberapa indikator menurut Uno (2014) yaitu (1) adanya hasrat dan keinginan berhasil, (2) adanya dorongan dan kebutuhan dalam belajar, (3) adanya harapan dan citacita masa depan, (4) adanya penghargaan dalam belajar, (5) adanya kegiatan yang menarik dalam belajar,(6) adanya lingkungan belajar yang kondusif.

Motivasi menurut Utami, Djatmika dan Sa'dijah (2017) dapat menjadi semangat siswa dalam memecahkan masalah. Siswa menjadi lebih bergairah dalam memecahkan masalah jika terdapat dorongan dalam diri siswa untuk melaksanakan tindakan. Motivasi belajar memberikan konstribusi yang baik pada kemampuan pemecahan masalah. Artinya, jika motivasi belajar tinggi maka kemampuan pemecahan masalah siswa juga tinggi. Menurut Olpado dan Heryani (2017) motivasi belajar memang memiliki korelasi yang baik dengan kemampuan pemecahan masalah, motivasi belajar memiliki nilai konstribusi sebesar $51,84 \%$ terhadap kemampuan pemecahan masalah. Pernyataan ini juga didukung oleh penelitian Aspriyani (2017) yang menyatakan bahwa terdapat pengaruh positif antara motivasi dan kemampuan pemecahan masalah siswa, hal ini ditunjukkan dengan setiap penambahan satu motivasi maka kemampuan pemecahan masalah siswa akan bertambah sebesar 0,706. Sejalan dengan itu penelitian yang dilakukan oleh Ulya (2016) juga memberikan deskripsi jelas bahwa kemampuan pemecahan masalah siswa dengan motivasi yang tinggi tergolong baik. Kedua penelitian tersebut menyebutkan bahwa motivasi belajar memiliki hubungan baik dengan kemampuan pemecahan masalah. Oleh karena itu diperlukan penelitian untuk mendeskripsikan lebih jauh bagaimana kemampuan pemecahan masalah ditinjau dari motivasi belajar pada siswa SMP/MTS.

\section{METODE PENELITIAN}

Penelitian ini bertujuan untuk mendeskripsikan kemampuan pemecahan masalah matematis siswa MTS Thariqul Hidayah Danau Baru ditinjau dari motivasi belajar. Jenis penelitian ini adalah penelitian deskriptif kualittatif. Adapun pendekatan dalam penelitian ini adalah pendekatan deskriptif yang bertujuan untuk mendeskripsikan apa yang saat ini berlaku. Populasi pada penelitian ini adalah siswa kelas IX B MTS Thariqul Hidayah Danau Baru Semester I Tahun Pelajaran 2019/2020 sebanyak 20 siswa. Alur penelitian ini dapat dilihat pada gambar 1 . 


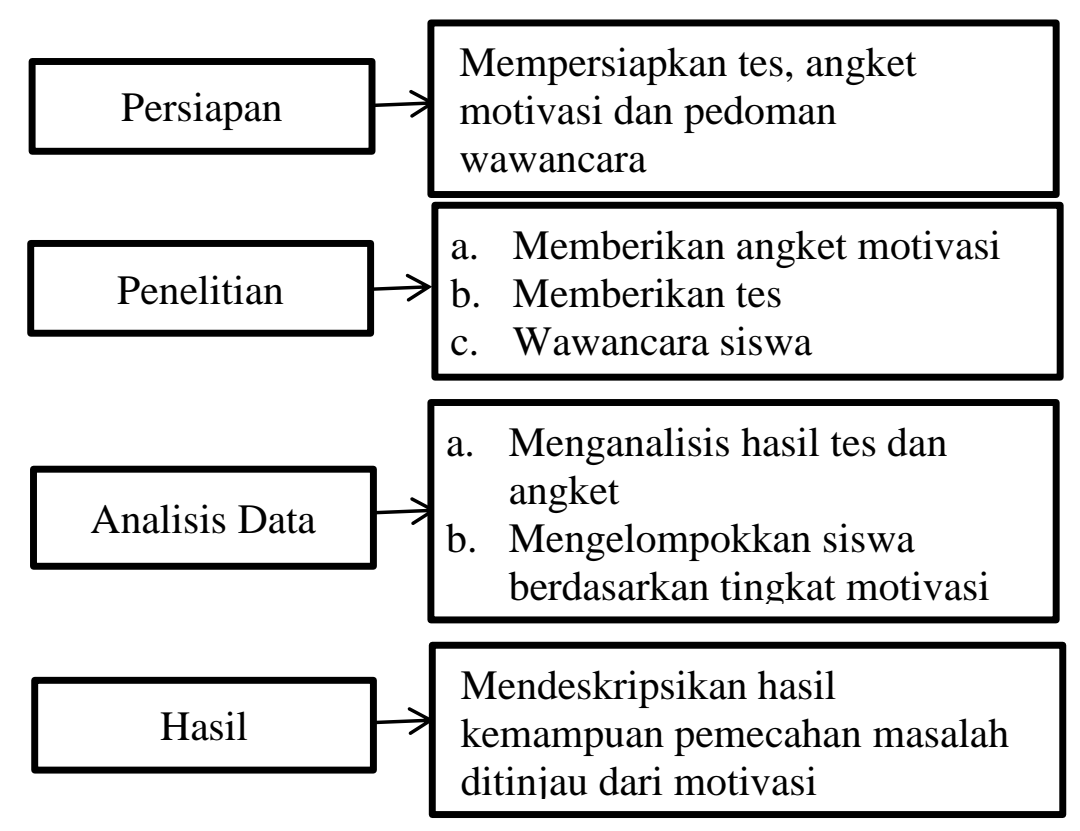

Gambar 1. Prosedur pada penelitian

Tahap persiapan yang dilakukan peneliti adalah mempersiapkan tes kemampuan pemecahan masalah dan angket motivasi belajar yang sudah divalidasi beserta dengan pedoman wawancara yang digunakan pada tahap penelitian. Tahap selanjutnya yaitu pelaksanaan penelitian, penelitian dilakukan dengan memberikan angket dan lembar tes kepada siswa yang menjadi popolasi penelitian dan melakukan wawancara dengan beberapa siswa untuk mendukung hasil lembar tes. Tahap ketiga adalah melakukan analisis data dengan mengolah angket menggunakan skala likert serta memeriksa lembar tes kemampuan pemecahan masalah. Tahap keempat adalah mendeskripsikann hasil kemampuan pemecahan masalah siswa ditinjau dari motivasi belajar. Motivasi belajar siswa dibagi menjadi tiga tingkatan yaitu tinggi, sedang dan rendah, sementara kemampuan pemecahan masalah juga dikelompokkan menjadi tiga yaitu kategori baik, sedang dan rendah.

Data pada penelitian ini dikumpulkan secara langsung oleh peneliti, sehingga instrumen utama penelitian ini adalah peneliti sendiri yang dibantu dengan instrumen berupa tes pemecahan masalah, angket, dokumentasi dan pedoman wawancara. Teknik pengumpulan data dalam penelitian ini menggunakan teknik tes dan non tes. Teknik tes digunakan untuk mendapatkan hasil kerja siswa dalam menyelesaikan soal pemecahan masalah, sedangkan teknik non tes menggunakan angket untuk memperoleh data motivasi belajar siswa serta pedoman wawancara untukg memperoleh data yang lebih rinci mengenai hasil tes yang siswa dapatkan 


\section{HASIL DAN PEMBAHASAN}

Hasil penelitian yang dilakukan terhadap 20 siswa dikelas IX B MTS Thariqul Hidayah Danau Baru digunakan untuk melihat tingkatan Motivasi belajar. Sesuai dengan metode penelitian, motivasi belajar siswa dibagi ke dalam tiga tingkatan yaitu motivasi tinggi, sedang dan rendah. Data keseluruhan tes angket disajikan pada tabel dibawah ini

Tabel 2. Data Hasil Angket Motivasi Belajar Siswa

\begin{tabular}{cc}
\hline Kategori & Jumlah siswa \\
\hline Tinggi & 6 \\
Sedang & 13 \\
Rendah & 1 \\
\hline
\end{tabular}

Hasil dari tabel 2 dapat dilihat bahwa pada kelas IX B MTS Thariqul Hidayah Danau Baru siswa dengan motivasi sedang memperoleh frekuensi paling banyak di kelas yaitu $65 \%$. Siswa dengan motivasi tinggi sebanyak enam orang dan siswa dengan motivasi rendah hanya ada satu orang. Setelah siswa dibagi berdasarkan tingkat motivasi, selanjutnya lembar tes kemampuan pemecahan masalah siswa dianalisis dan didapat data berikut

Tabel 3. Data Hasil Tes Kemampuan Pemecahan Masalah Siswa

\begin{tabular}{cc}
\hline Kategori & Jumlah siswa \\
\hline Baik & 4 \\
Sedang & 13 \\
Rendah & 3 \\
\hline
\end{tabular}

Berdasarkan data tabel 3 dapat diketahui bahwa siswa dengan kempuan pemecahan masalah sedang lebih banyak dari kategori lain. Siswa dengan motivasi baik memiliki frekuensi empat orang sedangkan motivasi rendah sebanyak tiga orang. Data kemampuan pemecahan masalah siswa ini kemudian dikelompokkan berdasarkan tingkatan motivasi belajar sehingga diperoleh data pada tabel berikut.

Tabel 4. Data Hasil Tes kemampuan pemecahan masalah ditinjau dari motivasi belajar

\begin{tabular}{cccc}
\hline Kemampuan & \multicolumn{3}{c}{ Motivasi Belajar Siswa } \\
\cline { 2 - 4 } $\begin{array}{c}\text { pemecahan } \\
\text { masalah }\end{array}$ & Tinggi & Sedang & Rendah \\
Baik & 3 & 1 & - \\
Sedang & 3 & 10 & - \\
Rendah & - & 2 & 1 \\
\hline
\end{tabular}

Tabel 4 menunjukkan bahwa siswa dengan motivasi belajar yang tinggi dan kemampuan pemecahan masalah yang baik hanya sebanyak tiga orang dan tiga orang lainnya memiliki kemampuan pemecahan masalah yang sedang. Siswa yang memiliki motivas belajar sedang hampir seluruhnya memiliki kemampuan pemecahan masalah yang 
juga sedang, satu orang siswa berada pada kategori kemampuan pemecahan masalah yang baik dan dua siswa berada pada kategori rendah. Siswa dengan motivasi belajar yang rendah hanya ada satu orang dan siswa tersebut juga memiliki kemampuan pemecahan masalah yang rendah.

\section{Kemampuan Pemecahan Masalah Siswa Motivasi Tinggi}

Siswa K-1 merupakan siswa dengan motivasi tinggi dan memiliki kemampuan pemecahan masalah yang baik. Siswa K-1 mampu menyelesaikan langkah pertama kemampuan pemecahan masalah yaitu understanding the problem atau memahami masalah yang terdapat di dalam soal. Terbukti dari 3 soal yang diberikan siswa menuliskan dengan tepat apa yang diketahui dan apa yang ditanyakan oleh setiap soal.

Langkah selanjutnya dari kemampuan pemecahan masalah adalah devising a plan atau membuat rencana penyelesaian. Siswa K-1 mampu menentukan rencana atau langkah untuk menyelesaikan soal. Siswa K-1 menggunakan informasi yang sudah di dapati untuk memperoleh informasi lain yang tidak terdapat pada soal untuk menyelesaikan masalah yang diberikan. Seperti pada soal nomor 3 siswa diminta menentukan dana yang dibutuhkan untuk memasang keramik pada sebuah kamar berbentuk persegi. Informasi yang diketahui dari soal adalah ukuran panjang dan lebar kamar, ukuran panjang dan lebar ubin yang akan di pasang, serta harga satu keping ubin. Siswa K-1 memulai pengerjaan dengan mencari berapa luas kamar dan luas satu keping ubin.

Langkah carrying out the plan atau melaksanakan rencana penyelesaian dilalui oleh siswa K-1 setelah memperoleh informasi tambahan yang dibutuhkan dari langkah menentukan rencana penyelesaian di awal. Siswa menggunakan cara yang tepat sehingga memperoleh jawaban yang benar. Siswa K-1 menjawab dua pertanyaan dengan benar dan satu pertanyaan di jawab keliru karena kesalahan perhitungan seperti pada soal ke 3. Siswa sudah memahami masalah dengan benar, melakukan rencana penyelesaian dengan benar dan juga melaksanakan rencana dengan tepat hanya keliru ketika perkalian saja.

Kesalahan perhitungan dapat terjadi diantaranya adalah karena siswa tidak memeriksa kembali jawaban mereka. Memeriksa kembali atau looking back merupakan langkah terakhir dari proses pemecahan masalah menurut Polya. Kegiatan memeriksa kembali menggunakan pemeriksaan secara khusus pada setiap langkah penyelesaian dan pemeriksaan secara umum untuk mengetahui masalah secara umum (Nuraini, Maimunah, \& Roza, 2019). Langkah ini dilakukan siswa dengan cara membuat kesimpulan dari jawaban yang diberikannya. 


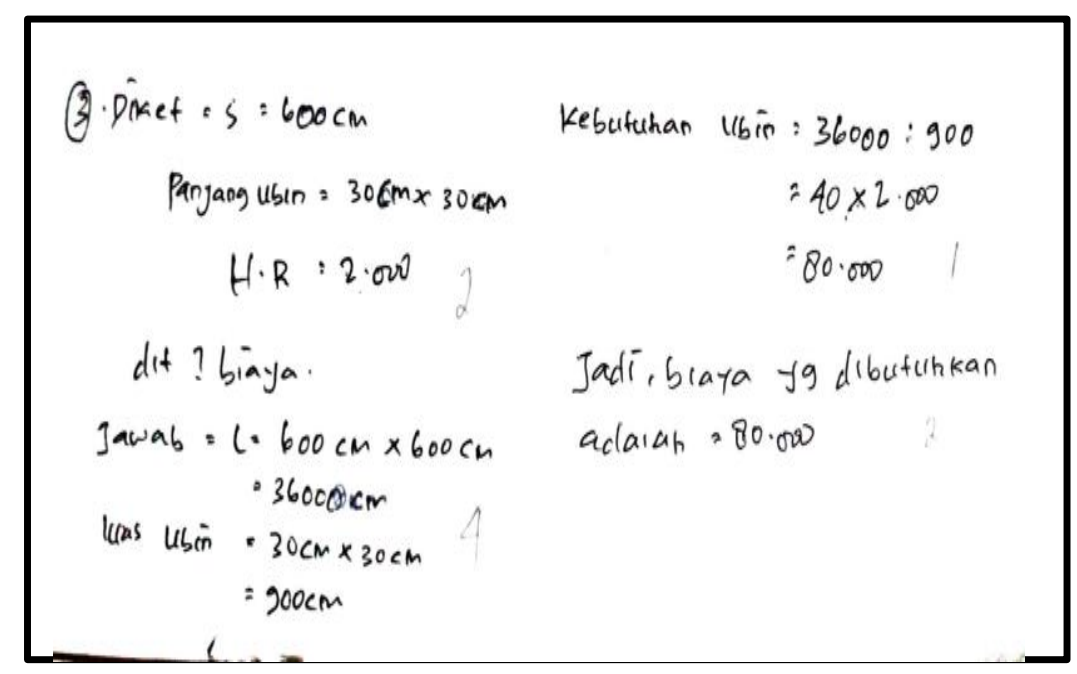

Gambar 2. Penyelesaian soal siswa K-1

Selain siswa K-1 ada pula siswa K-2 yang juga memiliki motivasi belajar tinggi namun memiliki kemampuan pemecahan masalah dalam kategori sedang. Siswa K-2 menjawab soal nomor 1 dan 2 dengan baik dan memenuhi setiap indikator kemampuan pemecahan masalah, namun pada soal nomor 3 siswa tidak menjawab sama sekali sehingga skor yang diperoleh siswa berkurang. Menyikapi hal tersebut maka dilakukan wawancara dengan siswa K-2 dan diperoleh informasi bahwa siswa tidak memiliki waktu yang cukup. Siswa terlalu lama memahami soal dan memikirkan langkah penyelesaian yang harus dilakukan sehingga ketika waktu habis soal ketiga tidak sempat siswa kerjakan. Kejadian seperti ini dapat dikarenakan oleh faktor-faktor lain diluar motivasi, seperti yang dinyatakan oleh Dwianjani, Candiasa dan Sariyasa (2018) bahwa kemampuan menentukan strategi penyelesaian merupakan faktor paling penting yang mempengaruhi kemampuan pemecahan masalah. Hal ini berarti ketika siswa sudah tidak mampu memikirkan strategi penyelesaian maka siswa tidak akan mampu melanjutkan ketahap selanjutnya yaitu melaksanakan rencanya dan berakibat pada kemampuan pemecahan masalah siswa akan kurang baik.

Secara keseluruhan dapat disimpulkan bahwa kemampuan pemecahan masalah siswa dengan motivasi tinggi tergolong baik. Siswa mampu memahami masalah dan menentukan rencana penyelesaian dengan tepat. Langkah melaksanakan rencana juga dilakukan siswa sesuai dengan rencana yang sudah ditentukan, hanya saja siswa kurang teliti dalam mengecek kembali jawaban yang diberikan sehingga kesimpulan akhir yang diberikan keliru. Hal ini senada dengan yang dinyatakan oleh Ulya (2016) bahwa siswa dengan motivasi belajar yang tinggi memiliki kemampuan pemecahan masalah yang baik terlihat dari setiap indikator pemecahan masalah dapat dipenuhi. 


\section{Kemampuan Pemecahan Siswa Motivasi Sedang}

Siswa dengan motivasi belajar sedang mampu memahami masalah dan menuliskan apa yang diketahui serta apa yang ditanya oleh soal. Siswa juga sudah mampu merencanakan penyelesaian soal, namun sebagian besar siswa bermasalah saat melaksanakan rencana penyelesaian yang akan di lakukan. Siswa K-18 adalah salah satu siswa dengan motivasi belajar sedang dan kemampuan pemecahan masalah sedang. Siswa K-18 dalam menyelesaikan masalah sudah memenuhi empat indikator kemampuan pemecahan masalah. Siswa membuat seluruh informasi yang diketahui dari soal dengan tepat. Selanjutnya siswa juga sudah mampu merencanakan penyelesaian yang akan dilakukannya namun, pada tahap melaksanakan rencana siswa tidak melakukannya dengan cara yang benar sehingga hasil yang diperoleh oleh siswa salah. Tahap memeriksa kembali sudah dilakukan oleh siswa dengan cara membuat kesimpulan dari jawaban yang diberikannya. Dari 3 soal yang diberikan, siswa K-18 mengalami masalah pada tahap melaksanakan rencana di setiap soal, sementara pada langkah lain siswa K-18 melakukan pengerjaan dengan baik.

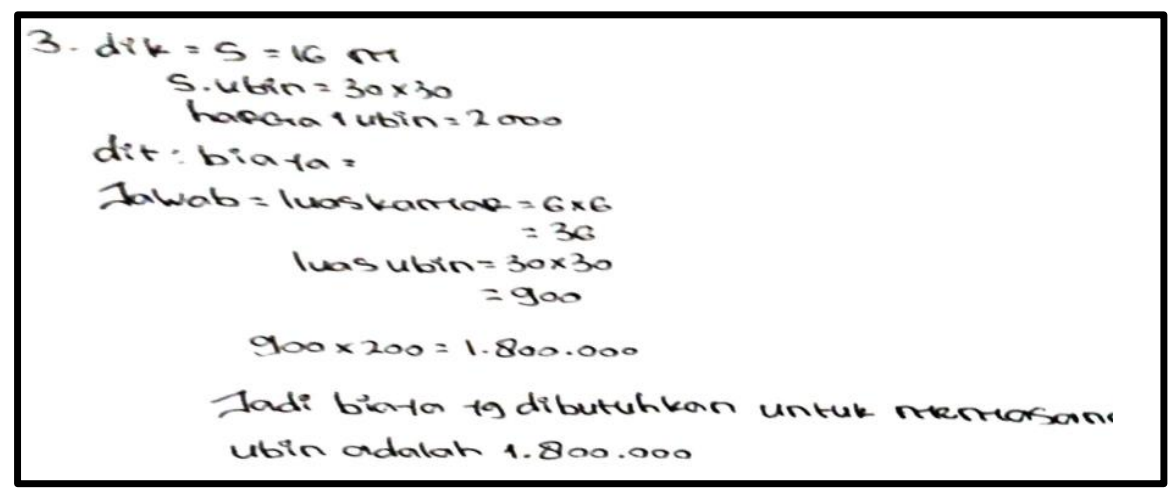

Gambar 3. Penyelesaian soal Siswa K-18

Siswa K-15 adalah siswa yang juga memiliki motivasi belajar sedang dan kemampuan pemecahan masalah sedang. Masalah yang terjadi pada siswa K-15 adalah siswa sudah memahami masalah yang diberikan dan menuliskannya pada bagian penyelesaian. Siswa mampu merencanakan penyelesaian masalah dengan menentukan langkah awal yang harus di lakukan dengan informasi yang dimiliki untuk mendapatkan informasi yang belum diketahui pada soal. Tetapi, pada tahap melaksanakan rencana siswa tidak melanjutkan pengerjaannya. Menyikapi hal tersebut maka dilakukan wawancara bersama siswa K-15 dan diperoleh informasi bahwa siswa tidak tahu bagaimana cara melanjutkan pengerjaan sooal setelah mendapat informasi baru. Siswajuga mengatakan bahwa informasi baru yang diperoleh masih kurang dan siswa tidak tahu bagaimana cara 
untuk melengkapi informasi lain, selanjutnya siswa juga mengatakan bahwa pada soal nomor 3 siswa tidak sempat menyelesaikan karena waktu yang diberikan sudah habis.

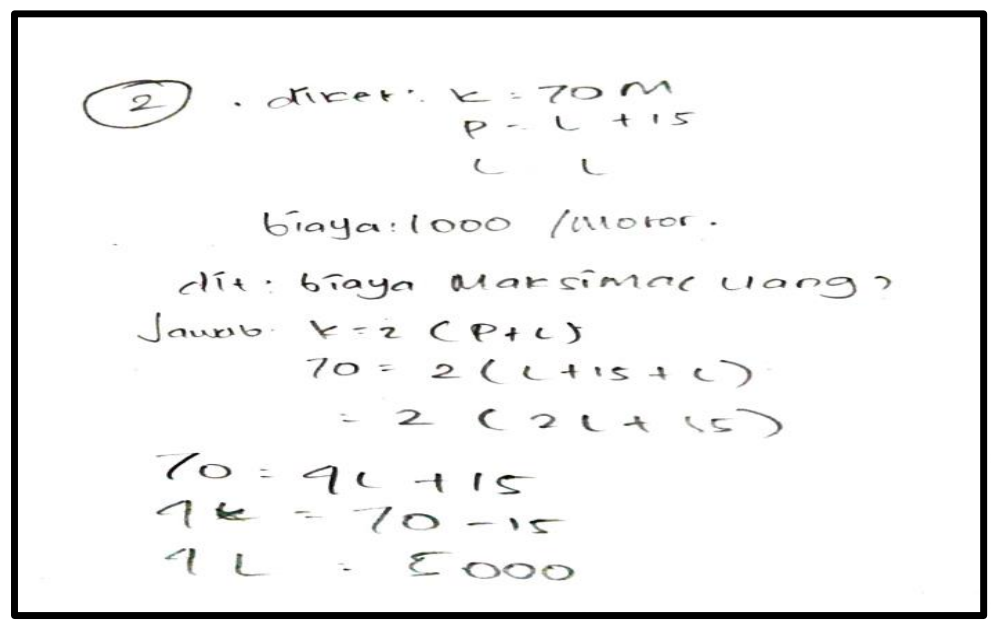

Gambar 4. Penyelesaian soal siswa K-15

Siswa K-9 adalah siswa dengan motivasi belajar sedang dan kemampuan pemecahan masalah yang rendah. Siswa K-9 tidak dapat memahami soal terlihat dari siswa menuliskan informasi soal dengan menulis apa yang diketahui dan ditanya, namun siswa tidak menuliskan dengan benar. Siswa menambah informasi yang tidak ada diketahui pada soal. Tahap selanjutnya yaitu merencanakan penyelesaian siswa juga tidak mampu menyusun rencana awal untuk memulai menyelesaikan soal sehingga siswa tidak bisa untuk ketahap melaksanakan penyelesaian. Seperti pada soal nomor 2, siswa mulai mengerjakan soal dengan menulis rumus luas persegi panjang, tetapi siswa tidak memasukkan angka yang diketahui pada soal, siswa menulis angka lain yang tidak trdapat pada soal dan tidak menyelesaikan jawaban yang diberikan. Berdasarkan hasil wawancara dengan siswa diperoleh informasi bahwa siswa tidak memahami soal dan siswa tidak tahu bagaimana cara untuk mendapat penyelesaian masalah sesuai yang diinginkan oleh soal.

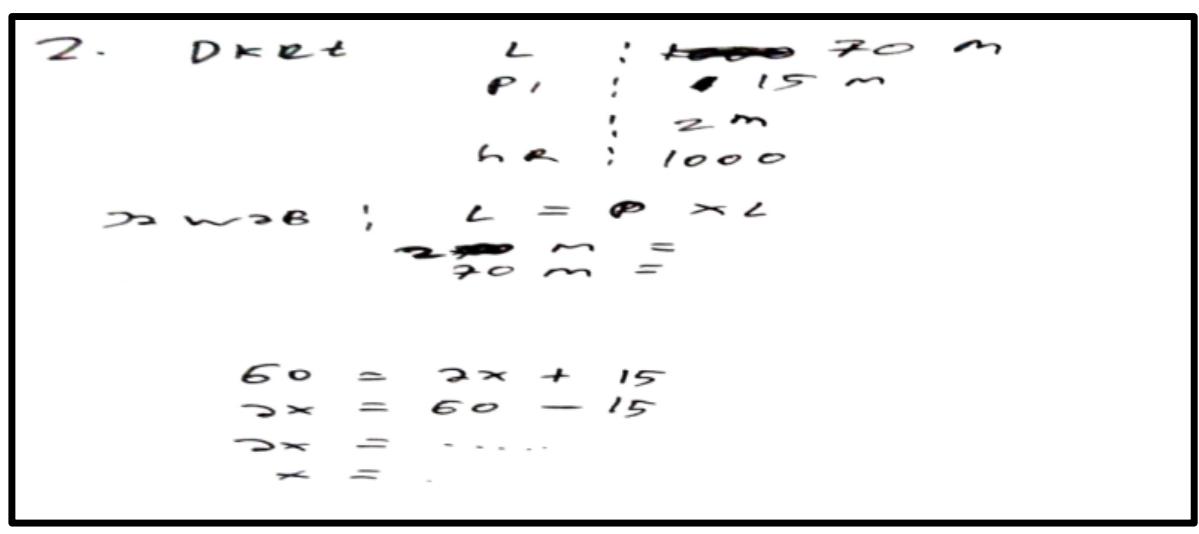

Gambar 5. Penyelesaian soal siswa K-9 
Hal seperti ini sesuai dengan pendapat Kudsiyah, Novarina, dan Lukman (2017) yang menyatakan faktor-faktor lain yang mempengaruhi kemampuan pemecahan masalah siswa yaitu kesulitan belajar, penguasaan pada materi, konteks soal, pemahaman, belajar sebelumnya, rumus, sikap, mood, perhatian, rasa malas, respon/tanggapan.

Secara keseluruhan dapat dikatakan bahwa siswa dengan motivasi sedang memiliki kemampuan pemecahan masalah relative sedang. Siswa mampu memahami masalah yang diberikan, mampu merencanakan penyelesaian dengan informasi yang diberikan soal namun kurang teliti ketika melakukan pelaksaan dari rencana penyelesaian sehingga hasil akhir yang siswa dapatkan tidak sesuai. Hal ini sesuai dengan yang dinyatakan oleh Aines (2017) bahwa siswa dengan motivasi belajar sedang mampu membangun pemahaman yang baru, memecahkan masalah yang ada, serta mengaplikasikan beberapa strategi yang tepat, tetapi siswa belum mampu merefleksikan proses pemecahan masalah yang disebabkan karena kurang teliti dalam mengerjakan soal.

\section{Kemampuan Pemecahan Siswa Motivasi Rendah}

Siswa dengan motivasi belajar yang rendah hanya ada satu yaitu siswa K-6. Siswa K-6 memiliki kemampuan pemecahan masalah yang juga rendah. Pada tahap memahami masalah soal nomor 1, siswa sudah menulis informasi yang diketahui dari soal. Setelah menulis apa yang diketahui dan ditanya oleh soal. Tahap merecanakan penyelesaian, siswa tidak merencakan penyelesaian apapun namun siswa sudah mendapat hasil yang diminta dari soal dan hasil yang didapat bernilai benar.

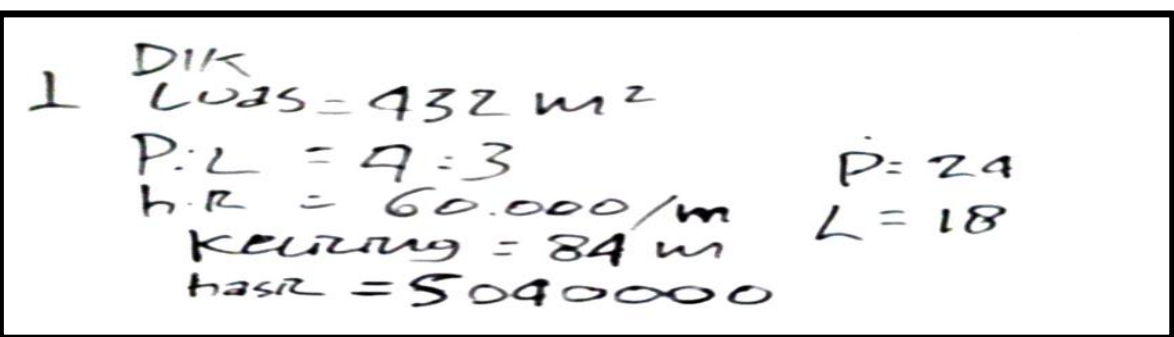

Gambar 6. Penyelesaian soal nomor 1 siswa K-6

Soal nomor 2 siswa juga sudah memahami masalah terlihat dari siswa menulis informasi yang terdapat pada soal. Siswa K-6 tidak mampu melanjutkan rencana penyelesaian yang sudah dipilih. Sama seperti siswa K-9, siswa K-6 juga memunculkan angka lain yang tidak ada di dalam soal sehingga siswa tidak mendapatkan hasil akhir yang diminta oleh soal. Soal nomor 3 juga tidak dapat di selesaikan oleh siswa. Siswa hanya menuliskan satu infor masi diketahui saja dari soal sementara informasi lainnya tidak siswa tuliskan. Berdasarkan hasil wawancara bersaa siswa K-6 didapat informasi bahwa siswa 
tidak mengerti bagaimana cara mendapatkan jawaban sesuai yang diminta oleh soal dan tidak tahu harus memulai menyelesaikan soal dari mana.

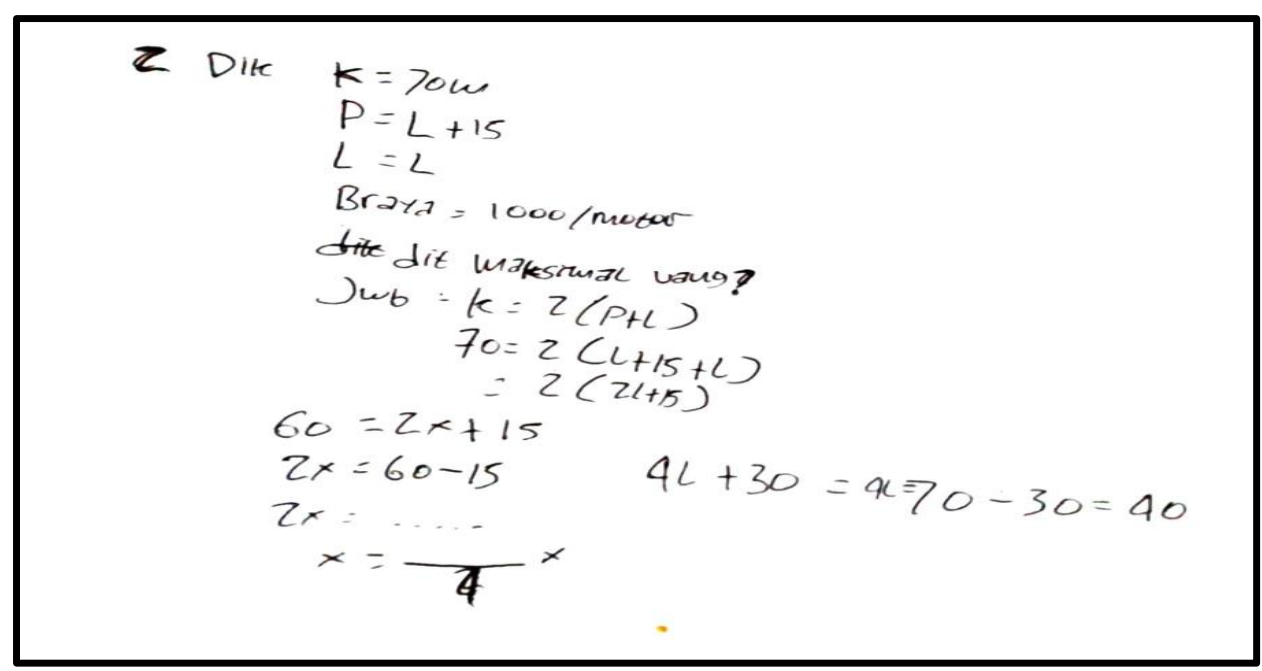

Gambar 7. Penyelesaian soal nomor 2 siswa K-6

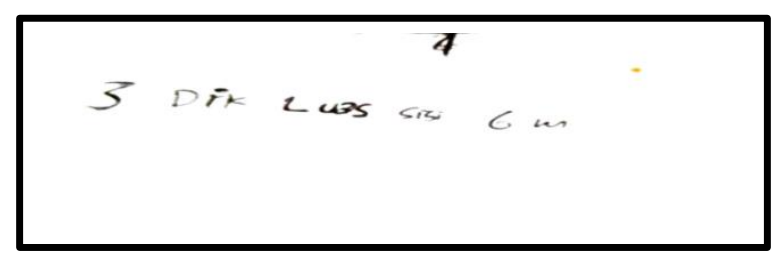

Gambar 8.Penyelesaian soal nomor 2 siswa K-6

Berdasarkan data siswa K-6 maka dapat dikatakan bahwa siswa dengan motivasi rendah memiliki kemampuan pemecahan masalah yang juga rendah. Siswa mampu untuk memahami masalah namun siswa tidak mampu untuk memilih strategi yang tepat untuk merencanakan penyelesaian dari masalah. Siswa tidak mampu merencanaka penyelesaian berakibat pada tidak mampunya siswa menyelesaikan masalah yang diberikan dan siswa tidak mengecek kembali jawaban yang diberikan.

\section{KESIMPULAN}

Berdasarkan hasil penelitian yang sudah dilakukan maka dapat disimpulkan bahwa sebagian besar siswa dengan motivasi belajar tinggi mempunyai kemampuan pemecahan masalah yang cenderung baik. Siswa mampu memenuhi ke empat indikator dari pemecahan masalah menurut Polya yaitu memahami masalah, merencanakan penyelesaian, melaksanakan penyelesaian dan juga memeriksa kembali jawaban yang sudah diberikan. Kesalahan yang sering terjadi pada siswa adalah siswa kurang teliti pada bagian operasi hitung sehingga hasil yang didapat tidak sesuai. 
Siswa dengan motivasi belajar sedang juga mempunyai kemampuan pemecahan masalah relatif sedang. Siswa mampu memahami masalah dan merencanakan strategi penyelesaian yang akan dilakukan. Kesalahan yang paling banyak terjadi pada siswa bermotivasi sedang adalah ketika melaksanakan rencana penyelesaian yang sudah dipilih siswa masih keliru sehingga langkah penyelesaiannya tidak tepat dan membuat jawaban yang diberikan salah. Pada tahap keempat yaitu mengecek kembali, sebagian siswa sudah melakukan dengan cara menulis kesimpulan jawaban yang mereka dapatkan.

Siswa dengan motivasi belajar rendah cenderung memiliki kemampuan pemecahan masalah yang rendah. Siswa mampu memahami masalah namun tidak mampu memilih rencana yang akan digunakan untuk menyelesaikan soal. Siswa tidak tahu harus memilih strategi yang cocok digunakan untuk masalah yang dihadapi sehingga berakibat siswa tidak mampu menyelesaikan masalah yang diberikan.

Selain itu, terdapat pula beberapa siswa yang memiliki motivasi belajar tinggi namun kemampuan pemecahan masalahnya masuk pada kategori sedang. Siswa dengan motivasi belajar sedang memiliki kemampuan pemecahan masalah baik dan juga rendah. Kejadian seperti ini dapat terjadi oleh beberapa faktor lain yang juga mempengaruhi kemampuan pemecahan masalah seperti kemampuan awal, kemampuan berfikir logis, kesulitan belajar, penguasaan pada materi, pemahaman, rasa malas, serta respon siswa pada soal.

\section{REKOMENDASI}

Penelitian ini berguna untuk guru agar lebih mudah mengenali kemampuan pemecahan masalah siswa berdasarkan tingkatan motivasi siswa. Selain itu, guru juga dapat meningkatkan motivasi belajar siswa dengan harapan kemampuan pemecahan masalah siswa juga ikut meningkat.

\section{UCAPAN TERIMAKASIH}

Terimakasih kepada pihak-pihak yang sudah membantu penelitian ini. Ucapan terimakasih khususnya kepada seluruh guru dan siswa MTs Thariqul Hidayah Danau Baru.

\section{REFERENSI}

Aines, A. V. (2017). Analisis kemampuan pemecahan masalah ditinjau dari motivasi belajar siswa smp melalui pembelajaran pbl berbantuan alat peraga dan asesmen formatif. Skripsi Universitas Negeri Semarang.

Aisyah, P. N. (2018). Analisis hubungan kemampuan pemecahan masalah matematis dan 
self confidence siswa smp. Journal On Education Volume 1, No. 1, 1(1), 58-65.

Aspriyani, R. (2017). Pengaruh Motivasi Berprestasi Siswa Terhadap Kemampuan Pemecahan Masalah Matematis. Jurnal Penelitian Dan Pembelajaran Matematika, 10(1). https://doi.org/10.30870/jppm.v10i1.1194

Ayu, Y. (2016). Analisis Kemampuan Pemecahan Masalah Matematis Siswa Kelas Xi Mipa Sma Negeri 1 Kota Jambi. Jurnal Ilmiah DIKDAYA ANALISIS, 12-19.

Cleopatra, M. (2015). Pengaruh Gaya Hidup Dan Motivasi Belajar Terhadap. Formatif: Jurnal Ilmiah Pendidikan MIPA.

Dwianjani, N., Candiasa, I, M., Sariyasa. (2018) Indentifikasi Faktor-faktor yang Mempengaruhi Kemampuan Pemecahan Masalah Matematika. Numerical: Jurnal Matematika Dan Pendidikan Matematika, Vol 2 No. 2 Desember 2018.

Himatul, U. (2016). Profil Kemampuan Pemecahan Masalah Siswa Bermotivasi Belajar Tinggi Berdasarkan Ideal Problem Solving. Jurnal Konseling GUSJIGANG Vol. 2 No. $1,2(1), 90-96$.

Kudsiyah, S. M., Novarina, E., \& Lukman, H. S. (2017). Faktor-Faktor Yang Mempengaruhi Kemampuan Pemecahan Masalah Matematika Kelas X Di Sma Negeri 2 Kota Sukabumi. Seminar Nasional Pendidikan 2017, 110-117.

Nisak, K. (2017). Pengaruh Penerapan Problem Based Learning Terhadap Kemampuan Pemecahan. Jurnal Kajian Pendidikan Matematika, 2348(1), 91-98.

Nuraini, Maimunah, \& Roza, Y. (2019). Analisis Kemampuan Pemecahan Masalah Siswa Kelas VIII SMPN 1 Rambah Samo Pada Materi Bangun Ruang Sisi Datar. Numerical: Jurnal Matematika Dan Pendidikan Matematika, 3(1), 63-76.

Olpado, S. U., Heryani, Y. (2017). Korelasi antara Motivasi Belajar dengan Kemampuan Pemecahan Masalah Matematik Peserta Didik menggunakan Model Problem Based Learning. Jurnal Penelitian dan Pengajaran Matematika, Vol 3. No 1, pp 63-70, Maret 2017.

Uno, B. H. (2014). Teori Motivasi \& Pengukurannya. Personnel Review.

Utami, F. D., Djatmika, E. T., \& Sa'dijah, C. (2017). Pengaruh Model Pembelajaran Terhadap Pemahaman Konsep, Sikap Ilmiah, Dan Kemampuan Pemecahan Masalah Matematis Ditinjau Dari Motivasi Belajar Siswa Kelas IV. Jurnal Pendidikan: Teori, Penelitian, Dan Pengembangan, 2 Nomor: 1(147), 1629-1638.

Vendiagrys, L., \& Junaedi, I. (2015). Analisis Kemampuan Pemecahan Masalah Matematika Soal Setipe Timss Berdasarkan Gaya Kognitif Siswa Pada Pembelajaran Model Problem Based Learning. Unnes Journal of Mathematics Education Research, 4(1), 34-41.

Warti, E. (2016). Pengaruh Motivasi Belajar Siswa terhadap Hasil Belajar Matematika Siswa di SD Angkasa 10 Halim Perdana Kusuma Jakarta Timur. Jurnal "Mosharafa", Volume 5, Nomor 2, Mei 2016.

Yusri, A. Y. (2018). Pengaruh Model Pembelajaran Problem Based Learning Terhadap Kemampuan Pemecahan Masalah Matematika Siswa Kelas Vii Di Smp Negeri Pangkajene. Jurnal "Mosharafa", Volume 7, Nomor 1, Januari 2018. 